\title{
Effect of composition and storage period on physico- chemical properties of jaggery based sweetmeat bar of maize
}

\section{A. K. Gupta}

Received : 23.02.2018; Revised : 06.02.2019; Accepted : 22.02 .2019

Author for Correspondence : A. K. Gupta AICRP on Post Harvest Engineering and Technology, College of Agricultural Engineering, Jawaharlal Nehru Krishi Vishwa Vidyalaya, Jabalpur (M.P.) India Email : drakg_68@hotmail. com
- ABSTRACT : A study was undertaken to develop jaggery based sweetmeat bars of maize flour. For the optimization of products, three ratios of jaggery and flours of maize viz., $4: 6,5: 5$ and $6: 4$ were selected in the study. Several physico-chemical properties (viz., moisture content, $\mathrm{pH}$, ash content, fat content and browning index), were evaluated for fresh samples vis-à-vis their counterparts packed in LDPE bags (100 gauge) and stored under ambient conditions for 30 and 60 days. Moisture content and browning index of products were higher for those having higher level of jaggery, whereas, $\mathrm{pH}$, ash content and fat content were lower. Maize samples prepared with highest level of jaggery had moisture content, 11.25 per cent, $\mathrm{pH}, 5.39$; ash content, 1.5 per cent fat content 1.853 per cent and browning index, 0.412 . During storage moisture content and browning index increased, whereas, $\mathrm{pH}$, fat content decreased, however, ash content remained constant.

- KEY WORDS : Jaggery, Maize flour, Sweet meat bar, Physico-chemical parameters

- HOW TO CITE THIS PAPER : Gupta, A.K. (2019). Effect of composition and storage period on physico- chemical properties of jaggery based sweetmeat bar of maize. Internat. J. Agric. Engg., 12(1) : 31-35, DOI: 10.15740/HAS/IJAE/12.1/31-35. Copyright@ 2019: Hind Agri-Horticultural Society. 